\title{
Terroristic Risks in Aviation Security: Jurisdictional Aspect
}

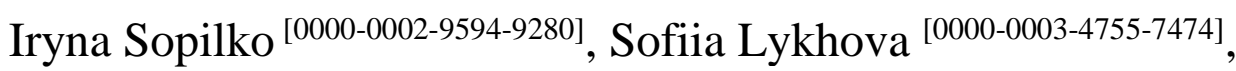 \\ Natalia Semchuk * [0000-0002-9357-9108]
}

National Aviation University, Kyiv, Ukraine

*k_kppip@ukr.net

\begin{abstract}
The article analyzes the challenges facing the security of civil aviation in the context of countering terrorism. Such challenges, which unite different sciences at the present stage, include the issue of multifaceted countering of terrorist threats. The peculiarity of such threats is that terrorism is currently an interstate phenomenon. Therefore, to protect civil aviation from terrorist threats, it is necessary to establish jurisdictional mechanisms, which have previously been used mainly under criminal law. Mechanisms of particular importance include the issue of universal jurisdiction. The universal jurisdiction, which first emerged to counter the criminal offenses of the Nazi regime, is now much more widespread. The article analyzes real cases of investigation of criminal offenses in the field of civil aviation, in situations where different countries have jurisdiction over these violations. The article concludes that in this case there can be no one universal solution to the problem and suggests real ways to solve these problems, which are applicable to different situations.
\end{abstract}

Keywords: aviation security, terroristic risk, jurisdictional mechanisms, universal jurisdiction.

\section{INTRODUCTION}

Risk is a comprehensive indicator of safety flights, which is an objective measure the possibility of an aviation accident, or a serious incident, or an incident in the context of the occurrence and existence of hazards [1]. The State Aviation Service in Order № 977 of 14.12.2017, among other threats, identifies threats related to the illegal handling of weapons, flights over conflict zones and terrorist threats [2-4]. Draft of Order of the Ministry of Infrastructure of Ukraine dated November 18, 2019 "On approval of the Instruction on assessment of the level of threats to the safety of civil aviation of Ukraine" pays attention to the risk assessment of both terrorist threats and threats of accidental armed destruction of aircraft for other reasons [5-7].Taken into account that terrorist attacks are generally understood by the state not only as risks in the field of civil aviation, but also as criminal offenses, countering them is impossible without criminal law.

All countries of the world identify the safety of Civil Aviation as one of the priorities of the national legislation. Ukraine also supports this approach. Liability for unlowful actions that pose a threat to the security of civil aviation establish in CC (Criminal Code) of Ukraine. A number of international conventions focused on security of civil aviation as a concept. The Convention on International Civil Aviation (the Chicago Convention) is the main convention that constitutes the basis of security of civil aviation. The Chicago Convention has a unique place in the civil aviation security system. First of all, the convention details the rights of the signatory countries with regard to air transportation and establishes general principles of flight safety. The convention also establishes a specialized UN agency responsible for the coordination and regulation of international air transportation, called the International Civil Aviation Organization (ICAO).As of November 2017, the Chicago Convention had 192 state parties (includes Ukraine).

Despite the fact that the draft describes in sufficient detail the interaction of bodies and services to combat such threats, without the use of tools developed by the sciences of the criminal law cycle, such counteraction is not possible. Given that many terrorist threats are currently interstate, countering them often also requires the 
cooperation of several states. In view of the above, the issue of using jurisdictional mechanisms to counter terrorist risks is relevant to ensuring the safety of civil aviation in Ukraine. Deviatkina, among these measures to reduce risks in the field of civil aviation proposes the development to appropriate legislative acts [1].

In view of the above, the purpose of this article is to study the issues of counteracting risks in the field of civil aviation through the use of jurisdictional mechanisms of criminal law.

\section{MATERIALS AND METHODS}

Normativism is the leading theory of methodology in Ukrainian jurisprudence. Normativism in Ukrainian science is in many respects the successor of the Marxist approach, which has been dominant in science for more than 50 years.In the field of social and legal sciences this scientific tradition is expecially distinguishable.

The law methodology in Ukraine is studied especially within the theory of state and law on the general theoretical level. That is, now in Ukraine a national approach to the formulation of legal research methods has been formed. There is still very little scientific work on the problems of the methodology of law. To use references to certain scientific methods, without deciphering in detail the essence of such methods and pointing to the author is traditional for Ukrainian legal science. Modern authors in Ukraine distinguish such methods as formal-logical, formal-dogmatic, comparativand historical e method.

Methodology as a doctrine exists on several levels, in particular philosophical, general scientific and specific scientific. Thus, it appears as a multilevel structure consisting of three levels. Their methods should be taken into account when classifying methods place and role in the process of scientific knowledge. Abstraction, induction and deduction, and the formal-logical method used among the main methods in the work. These methods are well known and common for legal research. Abstraction is one of main and important for the study of legal responsibility, which involves the delimitation of common features and properties from a particular subject and their separation formal other signs.

According to the formal-logical method, law as a social the phenomenon is defined formally justified, logically structured and clearly fixed system of rules, which built on the principle of subordination and consistent cynorms. The purpose of this method is to study the content and essence of using jurisdictional mechanisms to counter terrorist risks by systematizing the provisions and ideas that determine grounds, procedure of attraction and its limits.

Analysis is a formal-logical method, which consists in that the subject of the study is divided into parts, each of which investigated separately.

Induction provides an opportunity to car ryout know ledge from individual facts to general provisions about legal liability, and with the help of deduction car ryitout research by way of abstract to concrete, from general to special.

Secondary data of two types were used for the analysis: 1) texts of normative acts and scientific literature; 2) materials of real cases concerning two accidents of aircraft - MH 17 and The Ukrainian International Airlines Boeing 737-800.

\section{RESULTS}

A number of rules on criminal liability for unlowful actions in the sphere of safety of civil aviation has provided by Ukraine.

Theoretically, crimes in the aviation sphere, which are subject to liability on the principle of universal jurisdiction, can be committed with both intentional and negligent forms of guilt. However, this article will only analyze intentional crimes in this area, as they are more common and pose a greater danger.

Despite the large number of articles in the Criminal Code aimed at protecting the safety of civil aviation, the crimes under Articles 277 and 278 of the Criminal Code of Ukraine are of the greatest importance. The legislator determines the damage to aircraft, signaling and communication equipment,

airfield equipment, forced landing of the aircraft as the accident. Caused medium grave or grave bodily injury to the victim, or caused significant pecuniary damage or where they caused death of people is recognized as an aggravating circumstance. Article 277 of Criminal Code provides for criminal liability for damage to roads and vehicles. Criminal liability for hijacking of a rolling-stock, aircraft or sea/river vessel provides for by Article 278 of Criminal Code.

Michael P Scharf [8] indicates that there is currently extensive international anti-terrorism legislation. Among other actions for which responsibility is indicated at the international level, hijacking of aircraft occupies a special place. In the event that a country arrests such a hijacker, that country shall prosecute such person in accordance with the principle of general jurisdiction or extradite him or her.

At present, the issues related to air criminal law as a branch of criminal law are relatively poorly researched. However, in general, from a theoretical point of view, it can be divided into a general and a special part. One of the main issues related to a general part of air criminal law is jurisdiction [9]. 
Bassioun names at least five jurisdictional recognition theories in international law: 1) territorial principle based on the place of the criminal offense; 2 ) an active personal principle ("national" or nationality), usually based on the nationality of the alleged offender; 3 ) passive personal the principle based on the victim's nationality criminal offense; 4) the protective principle based in the national interest of the criminal offense; 5) the principle of universality based on the international nature of the criminal offense [10].

The most important for counteracting risks in civil aviation are the territorial principle and the principle of general jurisdiction. The issue of territorial jurisdiction is closely related to the legal regime of airspace. The Criminal Code of Ukraine regulates the exercise of jurisdiction in articles 6 to 8 [11]. According to this principle, any person who has committed a criminal offense in the territory of Ukraine is subject to criminal liability under the laws of Ukraine. In this case, the legislator considers a crime committed on the territory of Ukraine, if it was started, completed, continued or terminated on the territory of Ukraine and / or at least one of the accomplices acted on the territory of Ukraine.

This definition does not specify what is meant by the territory of Ukraine. The Law of Ukraine "On the State Border of Ukraine" [12] conclude that the state border of Ukraine is a line and a vertical surface that runs along this line that define the boundaries of the territory of Ukraine land, water, subsoil, air space.

However, the most important issue for air criminal law - at what height does the territorial jurisdiction of Ukraine extend, remains undisclosed. Unfortunately, no definition has been given in international law so far outer space and no delimitation of that space with air, although discussion of the issue has been going on for about 30 years UN Committee on Space.

The need to define the boundary between two types of environments is conditioned the difference in the legal modes of airspace, on the one hand, and space, on the other. After all, air space is divided into national (located above the territory of a particular State and under its sovereignty) and international, and space is indivisible, is "in common use", its exploration and use is for the benefit and in for the benefit of all mankind.

The issue of air vast and air delimitation is still unresolved outer space is primarily related to the presence of two opposite approaches of states to its solution: territorial (spatial) and functional. Proponents of the former believe that the upper boundary of airspace, which should be clearly defined at international level, at the same time will be the lower boundary of outer space, and their opponents will not see the need to define such a boundary, separating space and aviation activity depending on the functional purpose of the aircraft.

And while this issue is still on the agenda of the UN Legal Committee's Subcommittee on Space, a decision on the distinction between air and space has not been made (due to a lack of consensus), it is this lower bound of outer space that has become commonplace and in practical astronautics is the basis of two types of environments: the national sovereignty of the state does not extend to the space above the orbit of the lowest perihelion of the artificial satellite of the Earth, namely $100 \mathrm{~km}+-10 \mathrm{~km}$ above the ocean level.

That is, the height limits of the territorial jurisdiction of the state in this case may be the only case where criminal law enforcement is regulated by custom. The maximum flight altitude of today's aircraft is within 24-30 thousand $\mathrm{km}$. Therefore, for the time being, this question is of theoretical rather than practical interest. However, it is essential to reach an interstate consensus on the distinction between air and space.

In Art. 8 of the Criminal Code of Ukraine establishes the principle of universal jurisdiction [11]- regarding criminal offenses committed by foreigners or stateless persons outside Ukraine.

According to the principle of universal jurisdiction, persons who have committed criminal offenses outside Ukraine and do not reside permanently in Ukraine are criminally liable in the presence of three factors: 1) such acts are provided as crimes under the Criminal Code of Ukraine; 2) such crimes are classified as serious and particularly grave crimes; 3) encroachments are directed against the rights and freedoms of citizens of Ukraine or the interests of Ukraine.

According to Art. 12 of the Criminal Code of Ukraine, criminal offenses are divided into misdemeanors and crimes. Crimes are divided into minor, serious and particularly grave. A a serious crime is a crime for which the basic penalty in the form of a fine of not more than twenty-five thousand non-taxable minimum incomes of citizens or imprisonment for a term not exceeding ten years is provided. Particularly grave crime is a crime for which a basic penalty of more than twenty-five thousand nontaxable minimum incomes, imprisonment of more than ten years or life imprisonment is provided for [11].

Michael P. Scharf [8] also provide the hijacking of aircraft as example of terrorism. He cites the 9/11 tragedy and the PA 103 terrorist attack as examples of plane crashes that could be considered a crime against humanity.An improvised explosive device explosion during flight PA 103 in 1988 can be considered the biggest plane crash resulting from the terrorist 
attack.Thus, events on September 11 the scientist qualifies first as attack on the aircraft instead of actually act of terrorism. However, he points out that both plane crashes are clearly crimes against humanity.

So, even if it wasn't a clear act of terrorism per se, it could have been prosecuted as a criminal offense against humanity, even before an international court. Now it, it was of course an act of terrorism too because they used planes, and if person attack planes, that violates one of the antiterrorism conventions.

\section{DISCUSSION}

The first example is the MH 17 disaster. Marieke de Hoon (2017) [13] conclude that there are several states that could assert jurisdiction in their domestic courts over the downing of $\mathrm{MH} \mathrm{17.} \mathrm{First} \mathrm{of} \mathrm{all,} \mathrm{it} \mathrm{is} \mathrm{Ukraine,} \mathrm{over} \mathrm{the}$ territory of which this plane crash happened, that can insist on its own jurisdiction in accordance with the principle of territorial jurisdiction.

Also, the countries whose citizens were on board (Netherlands, Malaysia, Australia) and were killed can conduct investigations based on the passive personality principle. That is, at least four countries (Ukraine, the Netherlands, Australia, Malaysia) can claim their jurisdiction.

Marieke de Hoon (2017) also emphasize that there is also the possibility of prosecuting at the international level. The International Criminal Court (ICC) in the Hague is a potential avenue for holding the perpetrators of MH 17 to account. This international criminal court is permanent and extends its jurisdiction over the most serious crimes against humanity. Such crimes undoubtedly include the attack on flight MH 17. Simultaneously with the conviction of the guilty, this judicial institution has the authority to award reparations to victims of crime. Although Ukraine is not a signatory to the Rome Statute, which is fundamental to the work of this international tribunal, the scholar believes that Ukraine and the Netherlands could make a declaration in accordance with Article 12 (3) of the Rome Statute [13].

The Netherlands under the principle of passive personality, can prosecute all of the perpetrators involved in downing Flight MH 17 because at least one of the victims of MH 17 were Dutch nationals (in fact, of course, most were). The prosecution of international criminal offenses within the domestic criminal court system in the Netherlands, may be commited in accordance with the 2003 International Crimes Act.

In the end, there were many avenues for determining jurisdiction in the $\mathrm{MH} 17$. However, as a result, at the time of writing, the main investigation is taking place in the Netherlands (given first and foremost the number of victims).
Another example is a newer one. The Ukrainian International Airlines Boeing 737-800, flying to Kiev and carrying mostly Iranians and Iranian-Canadians, crashed shortly after taking off from Tehran's Imam Khomeini airport, killing all 176 people on board [14].

This happened on January 8, 2020. Iran's military announced early Saturday that it had accidentally shot down a Ukrainian passenger jet, blaming human error because of what it called the plane's sharp, unexpected turn toward a sensitive military base [15].

At the moment, as the "Delo" reports, Iran decided not to transfer "black boxes" to Ukraine from the downed Boeing because of the coronavirus, although Iran previously planned to deliver recorders to Ukraine, but this was postponed due to the outbreak of COVID-19 in Iran [16].

Comparing the case with MH 17, we hope that Ukraine, as a victim, will also demand the punishment of those responsible for the beating of Boeing in Kiev.

\section{CONCLUSIONS}

In our view, the potential for improving the potential for improving the air criminal law standards related to further work in specific sectors. In Ukrainian reality, the needs of practice are often outstripped by theoretical developments and their legal consolidation in normative documents. This is fully true of air criminal law. The study made the following conclusions:

And while this issue is still regulated on the agenda of the UN Legal Committee's Subcommittee on Space, a decision on the distinction between air and space has not been made (due to a lack of consensus), it is this lower bound of outer space that has become commonplace and in practical astronautics is the basis of two types of environments: the national sovereignty of the state does not extend to the space above the orbit of the lowest perihelion of the artificial satellite of the Earth, namely $100 \mathrm{~km}+-10$ $\mathrm{km}$ above the ocean level.

That is, the height limits of the territorial jurisdiction of the state in this case may be the only case where criminal law enforcement is regulated by custom. Therefore, for the time being, this question is of theoretical rather than practical interest.

In Art. 8 of the Criminal Code of Ukraine establishes the principle of universal jurisdiction - regarding criminal offenses committed by foreigners or stateless persons outside Ukraine.

According to the principle of universal jurisdiction, persons who have committed criminal offenses outside Ukraine and do not reside permanently in Ukraine are 
criminally liable in the presence of three factors: 1) such acts are provided as crimes under the Criminal Code of Ukraine; 2) such crimes are classified as serious and particularly grave crimes; 3) encroachments are directed against the rights and freedoms of citizens of Ukraine or the interests of Ukraine.

The provision according to which an individual, who commits war crimes or crimes against humanity or the crime of waging an aggressive war, could be held individually criminally responsible was first used during the Nuremberg tribunal. They could be prosecuted by an international tribunal or they could be prosecuted in any country of the world under universal jurisdiction. The fact that domestic law did not impose a penalty or did not say something was a crime not taken into account in the case of universal jurisdiction. The very application of universal jurisdiction is an example when in criminal law the fundamental principles and human rights override the rules of a particular article of the Criminal Code.

Two of the most recent cases of major plane crashes the MH 17 and the crash of a Ukrainian Airlines plane in Tehran on January 8, 2020, are examples of universal jurisdiction in air criminal law.

In the case of major aviation accidents, as a rule, many states can claim jurisdiction over a particular criminal offense, guided by different principles of their national law.

However, in accordance with Article 12 (3) of the Rome Statute, such States may refer the investigation of such an offense to the International Criminal Court.

However, at present, there is no common algorithm for resolving universal jurisdiction issues between several states in aviation criminal offenses.

The development of international instruments governing the application of universal jurisdiction between several countries in aviation criminal offenses is very relevant.

\section{REFERENCES}

[1] Deviatkina, S.S. (2011), "Risk rating in the safety management system at civil aviation airports", Bulletin of the National Aviation University, vol. 1, pp. 123-130.

[2] The State Aviation Service Order № 977 of 14.12.2017, On the establishment of a working group of the State Aviation Service to assess the risks and threats to civi laviation safety.

[3] Gururaj, H.L. Swathi, B.H. and Ramesh, B. (2018), "Threats, Consequences and Issues of Various Attacks on Online Social Networks", International
Journal of Education and Management Engineering, vol. 8, no. 4, pp. 50-60, DOI: 10.5815/ijeme.2018.04.05

[4] Sanjeev Puri (2012), "Intelligent Wireless Sensor Network System to shrink Suspected Terror from Militants", IJCNIS, vol. 4, no. 3, pp. 54-61, DOI: 10.5815/ijcnis.2012.03.07

[5] Draftof Order of the Ministry of Infrastructure of Ukraine dated November 18 (2019), On approval of the Instruction on assessment of the level of threats to the safety of civil aviation of Ukraine.

[6] Yogita Solanki and Sanjiv Sharma (2019), "A Survey on Risk Assessments of Heart Attack Using Data Mining Approaches", International Journal of Information Engineering and Electronic Business, vol. 11, no. 4, pp. 43-51, DOI: 10.5815/ijieeb.2019.04.05

[7] Xin Cao and Shidong Fan (2011), "The Navigation Risk Assessment Using Wavelet Neural Network", IJEME, vol. 1, no. 4, pp. 20-27, DOI: 10.5815/ijeme.2011.04.04

[8] Scharf Michael, P. and Williams Paul, R. (2010), Shaping Foreign Policy in a Time of Crisis: The Role of International Law and the State Department Legal Adviser.

[9] Sysoieva, V. and Semchuk, N. (2020), “Aviation and criminal jurisdiction. Public communication in science: philosophical, cultural, political, economic and IT context", Collection of scientific papers « $\Lambda$ ОГО $\Sigma$ » with Proceedings of the International Scientific and Practical Conference, vol. 5, may 1-5, Houston, USA: European Scientific Platform, pp 1112, DOI: $10.36074 / 15.05 .2020 . v 5.03$

[10] Bassiouni, M.Ch. (1974), "International Extradition and World Public Order New York": Oceana publication inc. Dobbis Ferry, 1296 p

[11] Criminal Code of Ukraine, available at: https://www.legislationline.org/documents/action/po pup/id/16257/preview

[12] Law of Ukraine "On the State Border of Ukraine", available at: https://zakon.rada.gov.ua/laws/show/1777-12

[13] Hoon de M. (2017), "Navigating the Legal Horizon: Lawyering the MH17 Disaster", Utrecht Journal of International and European Law, vol. 33 (84), pp. 90-119, DOI: $10.5334 /$ ujiel.368 
[14] "Ukrainian airplane with 180 aboard crashes in Iran: Fars", Reuters, 8 January 2020, Archived from the original on 8 January 2020.

[15] "Iran Says It Unintentionally Shot Down Ukrainian Airliner" (2020), The New York Times, 10 January.
[16] Iran decided not to hand over to Ukraine "black boxes" from a downed Boeing due to coronavirus (2020), Delo, 13 March, available at: https://delo.ua/econonomyandpoliticsinukraine/iranreshil-ne-peredavat-ukraine-chernye-jaschik-36601 